\title{
ANALISIS KEUNTUNGAN USAHA JAMUR TIRAM (Pleurotus sp) PADA BELLA FARM DI DESA MOKUPA KECAMATAN TOMBARIRI KABUPATEN MINAHASA
}

\author{
Cynthia Meylin Lahama \\ Paulus Adrian Pangemanan \\ Ribka Magdalena Kumaat
}

\begin{tabular}{ll}
\hline Naskah diterima melalui Website Jurnal Ilmiah agrisosioekonomi@ unsrat.ac.id & : Senin, 22 April 2019 \\
Disetujui diterbitkan & $:$ Jumat, 26 April 2019 \\
\hline
\end{tabular}

\begin{abstract}
ABSTRAC
The objective of this research is to analyze the profit received by Bella Farm in one production of Oyster Mushrooms for three months. The research was conducted in December 2018 to February 2019, starting from preparation to preparing the report. The data used are primary. Primary data was obtained from direct interviews with oyster mushroom business owner Bella Farm. While secondary data was obtained from the North Sulawesi Agriculture and Animal Husbandry Service, the internet through Google in the form of journal articles and theses related to this research. Data collected in this study are presented in table form and then described and analyzed using profit analysis. Profits are obtained from the difference between revenue and costs incurred. The results of the research showed that Bella Farm in Mokupa Village, Tombariri Sub-district, Minahasa Regency received a profit of $R p .24 .714 .705$ per one-time production process for three months at a cost of Rp. 22.185.295and the value of $R / C$ cost revenue is 2.11, which means that Bella Farm has a profit. *jnkd+eprm*
\end{abstract}

Keywords: oyster mushroom, profit analysis, Bella Farm, Mokupa Village, Minahasa Regency.

\begin{abstract}
ABSTRAK
Penelitian ini bertujuan untuk menganalisis keuntungan yang diterima oleh Bella Farm dalam satu kali berproduksi Jamur Tiram selama tiga bulan. Penelitian ini dilaksanakan pada bulan Desember 2018 hingga Februari 2019, mulai dari persiapan sampai pada penyusunan laporan. Data yang digunakan adalah data primer dan data sekunder. Data primer diperoleh dari wawancara langsung dengan pemilik usaha jamur tiram Bella Farm. Sedangkan data sekunder diperoleh dari Dinas Pertanian dan Peternakan Sulawesi Utara, internet melalui google berupa artikel jurnal dan skripsi yang berkaitan dengan penelitian ini. Data dikumpulkan dalam penelitian ini disajikan dalam bentuk tabel kemudian dideskripsikan dan dianalisis dengan menggunakan analisis keuntungan. Keuntungan diperoleh dari selisih antara penerimaan dan biaya yang dikeluarkan. Hasil penelitian menunjukkan bahwa Bella Farm di Desa Mokupa Kecamatan Tombariri Kabupaten Minahasa ini mendapatkan keuntungan sebesar Rp. 24.714 .705 per satu kali proses produksi selama tiga bulan dengan biaya sebesar Rp. 22.185.295 dan nilai R/C cost revenue sebesar 2,11 yang artinya Bella Farm memperoleh keuntungan. ${ }^{*}$ jnkd+eprm*
\end{abstract}

Kata kunci : jamur tiram, analisis keuntungan, Bella Farm, Desa Mokupa, Kabupaten Minahasa

Agrisosioekonomi:

Jurnal Transdisiplin Pertanian (Budidaya Tanaman, Perkebunan, Kehutanan, Peternakan, Perikanan), Sosial dan Ekonomi 


\section{PENDAHULUAN}

\section{Latar Belakang}

Indonesia merupakan negara agraris dengan luas lahan yang sebagian besar dikelola untuk pertanian dan keaneka ragaman hayati yang sangat beragam.Di negara agraris seperti Indonesia sektor pertanian mempunyai kontribusi penting baik terhadap perekonomian maupun terhadap pemenuhan kebutuhan pokok masyarakat karena sebagian besar penduduknya hidup dari hasil bercocok tanam atau bertani. Sektor pertanian terdiri dari sub sektor tanaman pangan, hortikultura, perkebunan, dan peternakan. Dari keempat sub sektor tersebut, hortikultura merupakan salah satu sub sektor yang terus berkembang dan mempunyai peranan penting dalam peningkatan pendapatan masyarakat.

Hortikultura salah satu sub sektor pertanian yang dikelompokan ke dalam empat kelompok komoditas yaitu buah-buahan, sayuran, tanaman hias, biofarmaka (tanaman obat-obatan). Kebutuhan produk hortikultura khususnya komoditas sayuran dewasa ini terus meningkat, akibat dari pola hidup sehat yang telah menjadi gaya hidup masyarakat sehingga membawa penduduk untuk mengetahui lebih luas akan manfaat pemenuhan gizi yang seimbang.

Salah satu tanaman hortikultura sayuran yang mempunyai gizi yang baik adalah Jamur tiram.Di Indonesia jamur tiram semakin diminati karena jamur tiram merupakan jenis jamur yang banyak di budidayakan.Selain memiliki badan buah yang dapat dimakan, jamur tiram juga mempunyai banyak khasiat karena mengandung karbohidrat, protein nabati yang tidak mengandung kolesterol, dan lemak jenuh yang rendah dibandingkan protein hewani dengan jumlah kalori yang sama.

Jamur tiram juga mengandung sejumlah vitamin yang penting, terutama kelompok vitamin $\mathrm{B}$, vitamin $\mathrm{C}$, dan provitamin $\mathrm{D}$ yang akang diubah menjadi vitamin $\mathrm{D}$ dengan bantuan sinar matahari. Kandungan vitamin B1 (tiamin), B2 (riboflavin), niasin dan provitamin D2 (ergosterol) nya cukup tinggi (Yuliarti 2017).

Budidaya jamur tiram baik untuk dikembangkan karena memiliki nilai ekonomi yang tinggi dan tidak membutuhkan luas lahan yang besar mengingat luas lahan pertanian di
Indonesia semakin lama mengalami penurunan. Bila dilihat dari potensi yang ada, usaha jamur tiram di Indonesia memiliki keunggulan tersendiri.Di Sulawesi Utara tempat usaha budidaya jamur jarang di ketahui dan masih kurang.

\begin{tabular}{clccc}
\multicolumn{6}{c}{ Tabel 1. Produksi Tanaman Sayuran Semusim di Sulawesi Utara (Kg) } \\
\hline \multirow{2}{*}{ No } & \multirow{2}{*}{ Nama Sayur } & \multicolumn{3}{c}{ Produksi (Kg) } \\
\cline { 3 - 5 } & & 2015 & 2016 & 2017 \\
\hline Kentang & 547.369 & 588.544 & 655.743 \\
2. & Kubis & 294.414 & 716.747 & 705.421 \\
3. & Jamur & 0 & 5.750 & 1.702 \\
4. & Bawang Daun & 341.092 & 487.181 & 373.866 \\
5. & Petsai/Sawi & 74.543 & 282.616 & 140.749 \\
\hline \multicolumn{5}{l}{ Sumber: Dinas Pertanian dan Peternakan Sulut 2018 }
\end{tabular}

Tabel 1 menunjukkan bahwa produksi tanaman sayur jamur masih sangat kurang tiap tahunnya dibanding dengan produksi tanaman sayuran lainnya. Pada tahun 2015tidak ada produksi tanaman sayuran jamur, pada tahun 2016 mengalami kenaikandengan produksi sebesar 5.750 kilogram, dan pada tahun 2017 mengalami penurunan produksi jamur yaitu sebsar 1.702 kilogram. Menurut jumlah produksi sayuran jamur tahun 2016 dan 2017 daerah Tomohon Selatan dan Tomohon Timur merupakan daerah penghasil sayuran jamur dengan tidak berproduksi secara terus menerus karenahanya sesuai keinginan petani untuk menanam. Hal ini akan berpengaruh pada turunnya kualitas maupun kuantitas jamur yang dihasilkan. Melihat produksi sayuran jamur tahun 2015 hingga 2017 terlihat bahwa petani sudah mampu membudidayakan sayuran jamur karena walaupun berfluktuasi, dengan melihat peluang pasarsayuran jamuryang cukup langkamengakibatkan harga sayuran jamur cukup mahal dibandingkan dengan tanaman sayuran lainnyasehingga usaha sayuran jamur menjanjikan keuntungan yang besar bagi petani.

Bella Farmadalahusaha budidaya jamur tiram yang berlokasi di Desa Mokupa Kecamatan Tombariri Kabupaten Minahasa. Memulai usaha budidaya jamur tiram putih pada tahun 2014 hingga saat ini, Bella Farm masih bersifat usaha perseorangan atau belum memiliki badan usaha resmi. Meski belum mempunyai badan usaha resmiberdasarkan observasi awal Bella Farm mampu mengelolah dan menghasilkan kualitas jamur yang baik untuk memperoleh keuntungan. Untuk itupenelitian ini di maksudkan untuk menganalisis keuntungan jamur tiram segar pada Bella Farm. 
Selain itu Bella Farm sendirisudah maju serta jelas pemasaraanya karena merupakan produsen jamur tiram putih yang ada di beberapa supermarket besar dan restoran ternama di kota Manado.

\section{Budidaya Jamur Tiram}

Dalam Warisno dan Dahana (2017), jamur tiram dapat diperbanyak dari setiap bagian tanaman dengan metode kultur jaringan.

1. Media Kultur Jaringan

Media kultur jaringan jamur tiram yang sering digunakan yaitu media potato dextrose agar (PDA), media agar-agar ekstrak malt, dan media lengkap.

(a) Potato Dextrose Agar (PDA)

(b) Agar-agar Ekstrak Malt

(c) Media Lengkap

2. Kultur Jaringan Jamur Tiram

Biakan murni jamur tiram diperoleh dengan mengkulturkan bagian jamur tiram, yang berasal dari tanaman sendiri maupun bahan kultur dari laboratorium atau balai besar mikrobiologi.

Biakan murni yang diperbanyak atau disubkultur disebut sebagai biakan induk. Ada dua media yang sering digunakan, yaitu:

1. Pembuatan Medi
(a) Media PDA Ekstrak Khamir
(b) Media Dedak

2. Pembuatan Biakan Induk

3. Pembuatan Media Produksi

Jamur tiram juga memiliki banyak jenis, dan masing-masing jenis memiliki manfaat dan konsumen yang berbeda.

1). Jamur Tiram Putih (Pleurotus ostreatus)

2). Jamur Tiram Merah (Pleurotus flabellatus)

3). Jamur Tiram Abu-abu (Pleurotus sayor caju)

4). Jamur Tiram Cokelat(Pleurotus cystidiosus)

\section{Konsep Produksi}

Menurut Soekartawi (2003), untuk menghasilkan suatu produk, maka diperlukan pengetahuan hubungan antara faktor produksi (input) dan produksi (output). Faktor-faktor yang mempengaruhi produksi antara lain :
1) Lahan Pertanian
2) Tenaga Kerja
3) Modal
4) Manajemen

\section{Harga}

Menurut Kotler dan Amstrong (2013), harga adalah sejumlah uang yang dibebankan atas suatu barang atau jasa atau jumlah nilai uang yang ditukar konsumen atas manfaat-manfaat karena memiliki atau menggunakan produk atau jasa tersebut.

\section{Konsep Penerimaan}

Menurut Boediono (2016), revenue adalahpenerimaan produsen dari hasil penjualan outputnya.Ada beberapa konsep revenue yang penting untuk analisa perilaku produsen.

Total Revenue (TR) yaitu penerimaan total produsen dari hasil penjualan outputnya. Total revenue adalah output kali harga jual output.

Keterangan:

$$
\mathbf{T R}=\mathbf{Q} \cdot \mathbf{P Q}
$$

$\mathrm{TR}=$ total penerimaan

$\mathrm{Q}=$ jumlah output yang dihasilkan atau yang dijual

$\mathrm{PQ} \quad=$ harga output

\section{Konsep Biaya}

Menurut Joesron dan Fathorrozi (2003), biaya dapat kita bagi berdasarkan sifatnya, artinya mengkaitkan antara pengeluaran yang harus dibayar dengan produk atau output yang dihasilkan, yaitu :

1) Biaya tetap

2) Biaya variabel

3) Biaya total

$$
\mathrm{TC}=\mathrm{TFC}+\mathrm{TVC}
$$

Keterangan :

$$
\begin{array}{ll}
\text { TC } & \text { : Total Cost } \\
\text { TVC } & : \text { Total Variabel Cost } \\
\text { TFC } & : \text { Total Fixed Cost }
\end{array}
$$

\section{Konsep Keutungan}

Menurut Soeharno (2009), secara sistematis konsep keuntungan dapat ditulis sebagai berikut :

$$
\pi=\mathrm{TR}-\mathrm{TC}
$$

Keterangan:

$\pi \quad=$ keuntungan (profit)

TR $=$ penerimaan total $=$ P.Q harga dikalikan dengan jumlah yang dijual

TC = biaya total, yaitu semua biaya yang dikeluarkan untuk menghasilkan suatu barang

Q = kuantitas barang yang dihasilkan atau yang dijual. 


\section{Konsep Analisis Revenue Cost (R/C)}

Menurut Soekartawi (2006) untuk mengetahui apakah usaha yang dilaksanakan mengalami keuntungan atau kerugian, maka diperlukan analisis R/C yang merupakan perbandingan antara penerimaan dan biaya. Secara matematis dapat ditulis sebagai berikut :

$$
\begin{aligned}
\mathrm{a} & =\mathrm{R} / \mathrm{C} \\
& =(\mathrm{Py} \cdot \mathrm{Y}) /(\mathrm{FC}+\mathrm{VC})
\end{aligned}
$$

Apabila :

$\mathrm{R} / \mathrm{C}=1$, Berarti usaha jamur tiram tidak untung atau tidak rugi

$\mathrm{R} / \mathrm{C}<1$, Berarti usaha jamur tiram ini rugi

$\mathrm{R} / \mathrm{C}>1$, Berarti usaha jamur tiram ini untung

\section{Penelitian Terdahulu}

Khoirul Umam (2012) dengan judul penelitian Analisis Pendapatan, Keuntungan, Dan Kelayakan Usaha Jamur Tiram Di Kabupaten Sleman.Tujuan penelitian adalah mengetahui pendapatan yang diterima dari usaha jamur tiram, mengetahui keuntungan jausaha jamur tiram dan mengetahui tingkat kelayakan usaha jamur tiram di Kabupaten Sleman. Hasil penelitian Menunjukkan bahwa pendapatan usaha jamur tiram di Kabupaten Sleman memperoleh pendapatan sebesar Rp. 8.322.183,33,keuntungan sebesar Rp. 5.446.516,66,- analisis $\mathrm{R} / \mathrm{C}$ ratio menunjukkan angka 1,46 ini menunjukkan bahwa usaha jamur tiram di Kabupaten Sleman layak untuk diusahakan.

Renie Connie (2008) dengan judul penelitian Analisis Pendapatan dan Titik Impas Usahatani Jamur Tiram Putih Pada Perusahaan Trisno Insan Mandiri Mushroom (TIMMUSH) Desa Cibuntu Kecamatan Ciampea Kabupaten Bogor Jawa Barat.Tujuan penelitian adalah membandingkan tingkatpendapatan dan titik impas usahatani jamur tiram putih di Perusahaan TIMMUSH sebelum dan setelah terjadi perubahan penggunaan alat sterilisasi dari kompor semawar ke kayu bakar dan mengidentifikasi alat sterilisasi manayang lebih efisien bagi Perusahaan TIMMUSH.Hasil penelitian menunjukkan bahwa Hasil analisis titik impas baik pada saat penelitian maupun setelah penelitian dilakukan menunjukkan bahwa pergantian alat sterilisasi dari komporsemawar ke kayu bakar membuat volume minimum penjualan jamur tiram putihdi Perusahaan TIMMUH menjadi lebih rendah dibandingkan pada saat pemilikperusahaan masih menggunakan kompor semawar. Alat sterilisasi terbaik bagi Perusahaan TIMMUSH adalah kayu bakarkarena memberikan pendapatan atas biaya tunai sebesar Rp 4.902.200 per musim.

\section{Rumusan Masalah}

Rumusan masalah permasalahan dalam penelitian ini adalah berapa besar keuntungan usaha jamur tiram (Pleurotus sp.) pada Bella Farm di Desa Mokupa Kecamatan Tombariri Kabupaten Minahasa?

\section{Tujuan Penelitian}

Tujuan penelitian ini adalah untuk menganalisis keuntungan usaha jamur tiram (Pleurotus sp) pada Bella Farm di Desa Mokupa Kecamatan Tombariri Kabupaten Minahasa.

\section{Manfaat Penelitian}

Ada beberapa manfaat yang dapat diperoleh dari penulisan penelitian ilmiah ini seperti: Bagi peneliti, penelitian ini sebagai salah satu karya ilmiah untuk mengembangkan pengetahuan dan wawasan mengenai usaha jamur tiram. Bagi pihak Bella Farm, dapat menjadi bahan masukan yang bermanfaat untuk meningkatkan keuntungan dalam usaha jamur tiram. Bagi pihak lain, diharapkan dapat menambah wawasan dan pengetahuan serta dapat dijadikan acuan dan informasi untuk penelitian selanjutnya.

\section{METODE PENELITIAN}

\section{Tempat dan Waktu Penelitian}

Penelitian ini dilaksanakan di Bella Farm Desa Mokupa Kecamatan Tombariri Kabupaten Minahasa sebagai tempat usaha budidaya jamur tiram (Pleurotus sp.). Penelitian ini akan dilakukan selama 3 bulan mulai dari bulan Desember 2018 - Februari 2019.

\section{Jenis dan Sumber Data}

Data yang digunakan dalam penelitian ini adalah data primer.Data primer merupakan data yang diambil oleh peneliti dilapangan langsung dari sumbernya yaitu pemilik usaha jamur tiram (Pleurotus sp.) pada Bella Farm Desa Mokupa Kecamatan Tombariri Kabupaten Minahasa.Data ini diperoleh dari wawancara secara langsung. 


\section{Teknik Pengumpulan Data}

Teknik pengumpulan data yang digunakan dalam penelitian ini adalah sebagai berikut:

1. Observasi (Observation) pengamatan secara langsung terhadap objek yang akan diteliti.

2. Wawancara (Interview)

3. Pencatatan

\section{Konsep Pengukuran Variabel}

Seluruh proses produksi jamur tiram putih pada Bella Farm adalah 90 hari atau sekitar tiga bulan lamanya.

Variabel-variabel yang diukur dan digunakan dalam penelitian ini adalah :

1. Produksi, yaitu Jumlah produksi jamur tiram yang dihasilkan dalam satu kali produksi/3 bulan $(\mathrm{Kg})$

2. Harga Produk, yaitu Harga jual jamur tiramputih per kilogram ( $\mathrm{Rp})$

3. Biaya Produksi, yaitu Besarnya biaya yang dikeluarkan satu kaliproduksi/3

bulanjamur tiram yang terdiri dari : (Rp)

a. Biaya Tetap (fixed cost)

1) Pajak (Rp)

a) Yaitu nilai pajak bumi dan bangunan (PBB)

b) Pajak Kendaraan

2) Listrik (Rp)

3) Air (Rp).

4) Biaya Penyusustan Peralatan\& Bangunan (Rp)

Rumus yang digunakan adalah :

$$
\text { Penyusutan }=\frac{N b-N s}{n}
$$

b. Biaya Variabel (variablecost)

1) Biaya Bahan Baku (Rp)

2) Biaya Bahan Penolong (Rp)

3) Tenaga Kerja (Rp)

4) Biaya Pengemasan (Rp)

5) BiayaTransportasi(Rp)

4. Penerimaan, yaitu perkalian antara produksi yang diperoleh dengan harga jual. (Rp)

5. Keuntungan, yaitu Nilai yang diperoleh dari hasil penjualan dikurangi dengan biaya-biaya yang dikeluarkan $(\mathrm{Rp})$

\section{Analisis Data}

Data dikumpulkan dari pihak Bella Farm kemudian dianalisis menggunakan Analisis Keuntungan yaitu menghitung selisish antara penerimaan dengan biaya-biaya yang dikeluarkan.

$$
\pi=\mathrm{TR}-\mathrm{TC}
$$

Keterangan:

$$
\begin{array}{ll}
\pi & =\text { keuntungan (profit) } \\
\mathrm{TR} & =\text { penerimaan total } \\
\mathrm{P} . \mathrm{Q} & =\text { harga dikalikan dengan jumlah yang } \\
& \text { dijual }
\end{array}
$$

TC = biaya total, yaitu semua biaya yang dikeluarkan untuk menghasilkan suatu barang

Q = kuantitas barang yang dihasilkan atau yang dijual.

Untuk menghitung penerimaan dapat dihitung dengan menggunakan rumus sebagai berikut :

\section{Keterangan:}

$$
\mathrm{TR}=\mathrm{Q} \cdot \mathrm{PQ}
$$

$\mathrm{TR}=$ total penerimaan

$\mathrm{Q}=$ jumlah output yang dihasilkan atau yang dijual

PQ = harga output

Untuk biaya total dapat dihitung dengan

menggunakan rumus sebagai berikut:

$$
\mathrm{TC}=\mathrm{TFC}+\mathrm{TVC}
$$

Keterangan :

TC : Total Cost

TVC : Total Variabel Cost

TFC : Total Fixed Cost

Kemudian untuk mengetahui apakah usaha jamur tiram ini menguntungkan atau tidak dapat dihitung dengan rumus :

$$
\begin{aligned}
\mathrm{a} & =\mathrm{R} / \mathrm{C} \\
& =(\mathrm{PQ} \cdot \mathrm{Q}) /(\mathrm{FC}+\mathrm{VC})
\end{aligned}
$$

Apabila :

$\mathrm{R} / \mathrm{C}=1$, Berarti usaha jamur tiram tidak untung atau tidak rugi

$\mathrm{R} / \mathrm{C}<1$, Berarti usaha jamur tiram ini rugi

$\mathrm{R} / \mathrm{C}>1$, Berarti usaha jamur tiram ini untung Dimana:
$\mathrm{a}=$ Revenue Cost Ratio
$\mathrm{R}=$ Revenue (Penerimaan)
$\mathrm{C}=\operatorname{Cost}$ (Biaya)
$\mathrm{PQ}=$ Output Price (Harga Produksi)
$\mathrm{Q}=$ Output (Jumlah Produksi)
$\mathrm{FC}=$ Fixed Cost (Biaya Tetap) 


\section{HASIL DAN PEMBAHASAN}

\section{Deskripsi Umum Bella Farm}

Bella Farm sebuah nama usaha yang didirikan oleh Inggrid Worung pada pertengahan tahun 2014. Bella Farm merupakan usaha yang bergerak dalam bidang pembudidayaan jamur tiram putih. Alasan pemilik memilih untuk memulai berusahatani jamur tiram karena terinspirasi dari hobi traveling yang pada waktu itu mengunjungi tempat-tempat budidaya jamur tiram yang ada diluar kota Manado serta melihat prospek usahatani jamur tiram yang cukup menjanjikandimana pada saat itu masih jarang bahkan belum ada orang yangmengusahakan komoditas tersebut dikota Manado dan dilihat dari sulitnya menemukan sayuran jamur tiram dipasar maupun supermarket-supermarket besar yang ada dikota Manado.

\section{Karakteristik Usaha Jamur Tiram Pada Bella Farm}

\section{Proses Produksi Jamur Tiram}

Kegiatan produksi Jamur Tiram Bella Farm dalam satu kali produksi selama 90 hari atau sekitar tiga bulan lamanya meliputi beberapa tahap.

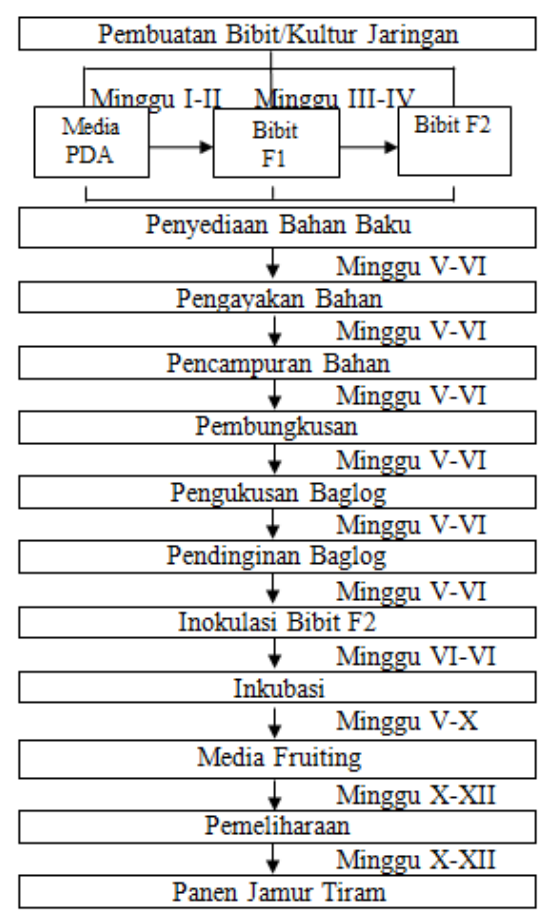

Diagram 1. Tahapan Produksi Jamur Tiram Putih
1) Proses pembuatan bibit per satu kali kultur jaringan

2) Penyediaan bahan baku seperti bibit, serbuk kayu, dedak, kapur pertanian, dan air.

3) Pengayakan bahan dilakukan sebelum proses pencampuran.

4) Pencampuran bahan bakudilakukan menggunakan mesin campur sampai campuran merata dengan kandungan air sekitar 50-60\%.

5) Pembungkusan baglog adalah kegiatan memasukan bahan-bahan yang sudah dicampur ke dalam plastic Poly Propylene.

6) Pengukusan baglog menggunakan dua drum sebesar $125 \times 100 \mathrm{~cm}$ dengan kapasitas isi masing-masing 150 baglog selama 6 jam dengan suhu $125^{\circ} \mathrm{C}$, dimaksudkan untuk mensterilkan baglog.

7) Pendinginan baglog setelah dikukus selama 1 hari.

8) Inokulasi yaitu proses pembibitan F2 yang dimasukkan kedalam baglog yang sudah disterilisasi.

9) Inkubasi dilakukan di selama satu bulan sampai baglog dipenuhi oleh miselium yang siap ditumbuhkan jamur.

10) Media fruiting/F3 adalah media baglog yang sudah diinokulasi.

11) Pemeliharaan dilakukan dengan penyiraman ruangan dan baglog 3 kali sehari.

12) Panen di lakukan setiap hari di pagi hari.

\section{Produksi Jamur Tiram}

Tabel 2 menunjukkan rincian produksi jamur tiram putih pada Bella Farm dalam satu kali produksi selama 90 hari atau sekitar 3 bulan.

Tabel 2. Produksi Usaha Jamur Tiram Putih per Satu Kali Produksi

\begin{tabular}{lcc}
\hline Keterangan & Satuan & Jumlah \\
\hline Bibit F2 & botol & 200 \\
Tingkat kegagalan kultur jaringan 5\% & botol & 10 \\
Jumlah botol produktif & botol & 190 \\
Kapasitas produksi & baglog & 3.000 \\
Tingkat kegagalan sterilisasi 5\% & baglog & 150 \\
Jumlah baglog & baglog & 2.850 \\
Tingkat kegagalan inkubasi 2\% & baglog & 57 \\
Jumlah baglog produktif & baglog & 2.793 \\
Konversi bobot hasil per baglog 300 gr & kg & 837.9 \\
\hline Sumber : Diolah dari Data Primer, 2019 & & \\
& &
\end{tabular}




\section{Lahan dan Bangunan}

Tabel 3 menunjukkan bahwa untuk ruang 1 kapasitas isi sebanyak 600 baglog sedangkan ruang 2 kapasitas isi sebanyak 5.400 baglog.

Tabel 3. Rincian Ruang Produksi Jamur Tiram Putih

\begin{tabular}{llcccc}
\multicolumn{6}{c}{ Bella Farm } \\
\cline { 1 - 4 } No. & Uraian & Luas & $\begin{array}{c}\text { Jumlah } \\
\text { Rak (unit) }\end{array}$ & $\begin{array}{c}\text { Jumlah } \\
\text { Tingkatan }\end{array}$ & $\begin{array}{c}\text { Kapasitas } \\
\text { Produksi } \\
\text { (baglog) }\end{array}$ \\
\hline 1 & Ruang 1 (Kanan) & $3 \times 4$ & 5 & 6 & 600 \\
2 & Ruang 2 (Kiri) & $8 \times 10$ & 9 & 5 & 5.400 \\
\hline \multicolumn{2}{l}{ Sumber : Diolah dari Data Primer, 2019 }
\end{tabular}

\section{Tenaga Kerja}

Dalam menjalankan sebuah usaha jamur tiram putih, Bella Farm memiliki lima orang tanaga kerja tetap luar kelurga dan dua orang tenaga kerja dalam keluarga. Tenaga kerja luar keluarga memiliki penyerapan tenaga kerja paling banyak dengan pembagian empat orang bekerja di tempat sebagai pekerja dalam setiap proses produksi, satu orang sebagai supir dan dua orang tenaga kerja keluarga sebagai pimpinan, bagian pembuatan bibit/kultur jaringan, serta pengawas dalam kegiatan budidaya. Semua tenaga kerja luar keluarga Bella Farm merupakan masyarakat setempat dan memiliki tingkat pendidikan Sekolah Menengah Atas (SMA).Dalam satu minggu diberlakukan enam hari kerja. Jam kerja dimulai pada pukul 08.00 WITA, istirahat siang selama satu jam pada pukul 12.00-13.00 WITA dan pulang pada pukul 17.00 WITA.

\section{Peralatan}

Dalam mengelolah usaha jamur tiram putih Bella Farm membutuhkan peralatan dan mesin dari mulai pembuatan bibit/kultur jaringan, pembuatan media tanam/baglog, hingga sampai pada pengemasan. Peralatan dan mesin yang digunakaan antara lain cawan petri, tabung reaksi, botol, panci presto, scapel, Bunsen, kompor tegangan tinggi, tabung gas $3 \mathrm{~kg}$, mesin aya, mesin campur, mesin press baglog, cincin paralon, pompa air, sprayer otomatic, sprayer manual, drum, sekop, cangkul, pisau, gunting, keranjang, timbangan digital, timbangan besar, alar wrapping.

\section{Harga}

Tabel 4 menunjukkan bahwa harga jual jamur tiram Bella Farm adalah Rp. 70.000/kg. Dalam setiap pemasarannya, jamur tiram dikemas dalam tatakan Styrofoam dengan berat 200 gram/pack.

\begin{tabular}{clr}
\multicolumn{3}{c}{ Tabel 4. Tempat dan Harga Pemasaran Jamur Tiram Putih } \\
\hline No. & Tempat Pemasaran & Harga/Kg (Rp) \\
\hline 1. & Hypermart & 70.000 \\
2. & Indo Grosir & 70.000 \\
3. & Freshmart & 70.000 \\
4. & Multi Mart & 70.000 \\
5. & Geprek Bensu & 70.000 \\
\hline Sumber $:$ Diolah dari Data Primer, 2019
\end{tabular}

\section{Biaya Produksi}

\section{Biaya Tetap(Fixed Cost)}

Biaya tetap adalah biaya yang besarnya tidak tergantung pada jumlah produksi atau biaya yang tidak berubah-ubah. Tabel 5 merupakan perincian biaya tetap usaha jamur tiram putih dalam satu kali produksi pada Bella Farm.

\begin{tabular}{clr}
\multicolumn{2}{c}{ Tabel 5. } & Biaya Tetap Usaha Jamur Tiram Putih dalam Satu Kali Produksi \\
\hline No & \multicolumn{1}{c}{ Jenis Biaya } & Jumlah (Rp) \\
\hline 1 & Pajak Bumi dan Bangunan & 21.750 \\
2 & Pajak Kendaraan & 131.720 \\
3 & Listrik & 1.500 .000 \\
4 & Air & 200.000 \\
5 & Biaya Penyusutan Alat & 1.703 .075 \\
\hline \multicolumn{2}{l}{ Total } & 3.556 .545 \\
\hline Sumber $:$ Diolah dari Data Primer, 2019
\end{tabular}

\section{Biaya Variabel}

Biaya variabel adalah biaya yang dikeluarkan tergantung pada besar kecilnya skala produksi yang dilakukan. Tabel 6 merupakan perincian biaya variabel usaha jamur tiram putih per satu kali produksi pada Bella Farm.

\begin{tabular}{clr}
\multicolumn{2}{c}{ Tabel 6. Biaya Variabel Usaha Jamur Tiram Putih dalam Satu Kali Produksi } \\
\hline No & Jenis Biaya & Jumlah (Rp) \\
\hline 1 & Biaya Bahan Baku & 2.493 .500 \\
2 & Biaya Bahan Penolong & 1.213 .000 \\
3 & Biaya Tenaga Kerja & 1.500 .000 \\
4 & Biaya Pengemasan & 1.422 .250 \\
5 & Biaya Transport & 2.000 .000 \\
\hline \multicolumn{2}{c}{ Total } & 18.628 .750 \\
\hline \multicolumn{2}{c}{ Sumber : Diolah dari Data Primer, 2019 }
\end{tabular}

\section{Biaya Total}

Biaya total adalah jumlah dari biaya tetap dengan biaya variabel. Tabel 7 merupakan perincian biaya usaha jamur tiram putih pada Bella Farm.

\begin{tabular}{clr} 
Tabel 7. & $\begin{array}{l}\text { Biaya Total Usaha Jamur } \\
\text { Produksi }\end{array}$ & Tiram Putih dalam Satu Kali \\
\hline No. & Komponen Biaya & Nilai Biaya (Rp) \\
\hline 1. & Biaya Tetap & 3.556 .545 \\
2. & Biaya Variabel & 19.128 .750 \\
\hline \multicolumn{2}{c}{ Total Biaya } & 22.185 .295 \\
\hline Sumber : Diolah dari Data Primer, 2019
\end{tabular}

\section{Penerimaan}

Penerimaan merupakan perkalian antara jumlah produksi jamur tiram putih dengan harga jual per kilogram. Tabel 8 menunjukkan besar penerimaan pada usaha jamur tiram putih Bella Farm di Desa Mokupa Kecamatan Tombariri Kabupaten Minahasa per satu kali produksi dari bulan Desember 2018 - Februari 2019 yaitu sebesar Rp. 46.900.000. 
Tabel 8. Penerimaan Usaha Jamur Tiram Putih dalam Satu Kali Produksi

\begin{tabular}{lc}
\hline Keterangan & Jumlah \\
\hline Jumlah baglog produktif & 2.793 baglog \\
Konversi bobot hasil per baglog $300 \mathrm{gr}$ & 837,9 kilogram \\
Jamur tiram terjual & 670 kilogram \\
Harga jual perkilogram & Rp. 70.000 \\
\hline Total Penerimaan & 46.900 .000 \\
\hline Sumber : Diolah dari Data Primer, 2019
\end{tabular}

\section{Keuntungan}

Sesuai dengan tujuan penelitian ini untuk menganalisis seberapa besar keuntungan yang diperoleh Usaha Jamur Tiram Putih pada Bella Farm, maka dilakukan analisis keuntungan berdasarkan penerimaan dari hasil penjualan jamur tiram dikurangi dengan semua biaya yang dikeluarkan selama proses produksi jamur tiram putih. Tabel 9 menunjukkan bahwa keuntungan pada usaha jamur tiram putih segar Bella Farm per satu kali produksi selama bulan Desember 2018 Februari 2019 yaitu sebesar Rp. 24.714.70.

\begin{tabular}{lc} 
Tabel 9. Keuntungan Usaha Jamur Tiram Putih dalam Satu Kali Produksi \\
\hline Keterangan & Jumlah (Rp) \\
\hline Penerimaan & 46.900 .000 \\
Total Biaya & 22.185 .295 \\
Keuntungan & 24.714 .705 \\
\hline Sumber : Diolah dari Data Primer, 2019
\end{tabular}

\section{Analisis Revenue Cost Ratio}

Tabel 10 menunjukkan bahwa nilai rata-rata $\mathrm{R} / \mathrm{C}$ ratio untuk Usaha Jamur Tiram dalam satu kali produksibulan November 2018 - Februari 2019 sebesar 2,11 . Nilai R/C menunjukkan angka > 1, maka dapat disimpulkan bahwa usaha jamur tiram ini menguntungkan secara ekonomi.

\begin{tabular}{lr} 
Tabel 10. & $\begin{array}{l}\text { Revenue Cost Ratio usaha Jamur Tiram Putih dalam Satu } \\
\text { Kali Produksi }\end{array}$ \\
\hline Keterangan & Jumlah (Rp) \\
\hline Penerimaan & 46.900 .000 \\
Total Biaya & 22.185 .295 \\
Keuntungan & 24.714 .705 \\
\hline R/C Ratio & 2,11 \\
\hline Sumber : Diolah dari Data Primer, 2019
\end{tabular}

\section{KESIMPULAN DAN SARAN}

\section{Kesimpulan}

Berdasarkan hasil penelitian tahapan pembuatan media tanam/baglog merupakan proses produksi yang memakan biaya paling besar namun usaha jamur tiram pada Bella Farm tetap menguntungkan. Keuntungan usaha jamur tiram putih dalam satu kali berproduksi selama tiga bulan dari bulan Desember 2018 - Februari 2019 sebesar Rp. 24.714.705 dengan nilai $\mathrm{R} / \mathrm{C}$ ratio yang $>1$ yaitu sebesar 2,11 yang berarti sangat menguntungkan.

\section{Saran}

Kendala yang dihadapi Bella Farm adalah belum bisa untuk menjamin jumlah tetap produksi jamur tiram yang akan dikirimkan ke setiap mitra penjualan karena beberapa faktor-faktor kegagalan produksi. Untuk itu sebagai saran Bella Farm perlu terus untuk mengembangkan usaha jamur tiram putih dengan memperhatikan penyebab setiap tingkat kegagalan dari tahapan-tahapan produksi, sehingga Bella Farm dapat memenuhi permintaan dari setiap konsumen.Karena jika produksi bertambah maka dapat meningkatkan keuntungan bagi Bella Farm.

\section{DAFTAR PUSTAKA}

Connie R. 2008 Analisis Pendapatan dan Titik Impas Usahatani Jamur Tiram Putih Pada Perusahaan Trisno Insan Mandiri Mushroom (TIMMUSH) Desa Cibuntu Kecamatan Ciampea Kabupaten Bogor Jawa Barat.Program Sarjana Ekstensi Manajemen Agribisnis Fakultas Pertanian Institut Pertanian Bogor.

Dinas Pertanian dan Peternakan Sulawesi Utara. 2019. Produksi Tanaman Sayuran Semusim di Sulawesi Utara.

Joesron, T.S. \& Fathorrozi, M. 2003. Teori Ekonomi Mikro.Edisi pertama. Salemba Empat. Jakarta.

Kotler, P. \& G. Amstrong. 2013. Prinsip-prinsip Pemasaran, Edisi ke-12. Penerbit Erlangga. Jakarta

Soekartawi. 2003. Teori Ekonomi Produksi. Raja Grafindo Persada. Jakarta. 2006. Agribisnis Teori dan Aplikasi. RajawaliPress. Jakarta.

Umam, K. 2012. Analisis Pendapatan, Keuntungan, Dan Kelayakan Usaha Jamur Tiram Di Kabupaten Sleman. Volume IV, Nomor 1.Program studi Agribisnis Fakultas Pertanian Universitas Janabadra. Yogyakarta.

Warisno dan Dahana, K. 2017. Tiram Menabur Jamur Menuai Rupiah.Cetakan kedua. Gramedia Pustaka Utama. Jakarta. 